\title{
LEARNING METHOD USING COMMUNICATIVE APPROACHES TO ENGLISH GRAMMAR TEACHING
}

\author{
Wilujeng Asih Purwani \\ Universitas Billfath
}

\section{INFO ARTIKEL}

Diterima: 11-12-2020

Disetujui: 1-2-2021

\begin{abstract}
Abstrak: Penguasaan grammar pada mata kuliah Basic English Grammar mahasiswa semester pertama di Universitas Billfath masih rendah sehingga diperlukan metode pengajaran yang tepat untuk mengakomodasi permasalahan tersebut yaitu pendekatan komunikatif dengan metode pembelajaran diskusi kelompok dan metode pembelajaran dengan presentasi. Penelitian ini bertujuan untuk mengetahui apakah diskusi kelompok dan presentasi dapat meningkatkan pemahaman dan penguasaan mata kuliah Basic English Grammar. Empat kelompok diskusi dengan total 16 mahasiswa semester pertama ditemukan setelah pretest. Diskusi kelompok dilakukan pada setiap hari perkuliahan (14 pertemuan). Hasil akhir perkuliahan ditentukan dengan posttest. Presentasi individu dilakukan di akhir perkuliahan. Uji t digunakan untuk menganalisis variabel skor pretes, postes, dan presentasi. Uji t Mann Whitney menunjukkan perbedaan yang signifikan sebesar $0,001<0,05$ antara skor pretes dan skor postes. Perbedaan signifikan 0,026<0,05 juga diperoleh antara skor pretes dan skor presentasi. Analisis data menunjukkan bahwa proses perkuliahan dengan metode diskusi kelompok secara signifikan meningkatkan pemahaman dan penguasaan mahasiswa mata kuliah Basic English Grammar, sehingga membantu penguasaan materi tes presentasi.
\end{abstract}

Abstract: The mastery of basic English grammar for first semester students in University of Billfath is still low. So that the right teaching method is needed to accommodate the problem, namely communicative approach with group discussion and presentation learning method. This research is aimed to find out whether group discussion and presentation can improve the students' understanding and mastery Basic English Courses. Four discussion group with a total of 16 first semester students were found after the pretest. Group discussions are conducted on each lecture day (14 meetings). The final results of the lecture are determined by posttest. Individual presentations are carried out at the end of the lecture. The $t$ test is used to analyze the variables of the pretest, posttest, and presentations scores. The Mann Whitney $t$ test showed a significant difference of 0,001 < 0.05 between the pretest score and the posttest score. A significant difference of $0.026<0.05$ was also obtained between the pretest score and the presentation score. The data analysis indicated that the lecture process with the group discussion method is significantly improved student understanding and mastery of Basic English Grammar courses, so that is help mastery the presentation test material

Correspondence Address : Komplek PP. Al-Fattah Siman Sekaran Lamongan

Name

Affiliation

Wilujeng Asih Purwani

: University Billfath 
KARANGAN: Jurnal Kependidikan, Pembelajaran, dan Pengembangan, Vol 03, No 01, Bulan Februari, Tahun 2021, Hal 1-6

\author{
Alamat instansi $\quad:$ Komplek PP. Al-Fattah Siman Sekaran Lamongan \\ Surel \\ :wilujengasihp@gmail.com
}

In the English education study program, grammar is a compulsory and is one of the important subjects. Crhistison, Ann, Christian, Duff and Spada (2015) have pointed out that grammar is an important part of learning any language including English. Furthermore grammar mastery will facilitate communication with English. The method of learning English is growing, from the one originally focused on the approach to memorizing the grammar formula now changing with the communicative approach since the communicative believed to make it easier for students to understand grammar rather than memorizing grammar formulas. (Thomas, 1999)

Gardner (2018) once remarked that it is important for teachers to be able to access and apply information about the complexities of grammatical that relate to language and to learning. To provide fun grammar learning solution, English Education Study Program of Billfath applies effective grammar learning methods to make it easier to understand with some forms of communicative approaches. These are group discussions and presentations which includes receptive and productive skills. Ghofur (2013) indicated that good english learning requires a balance between receptive and productive skills. Hwang (2016) also stated that teaching strategies with discussions provide many opportunities for students to get solutions to problems, facilitate understanding of certain topics and individual knowledge acquisition, and build students' critical thinking. Active discussion in English learning activities has the potential to be applied while the lecturers only acted as facilitators in the discussion.

One of the important competencies that must be mastered by students is the ability to present well, especially for student teacher candidates who will become professional educators. Canale and Swain (1980) suggests theoretical framework for teacher training, teacher must have a fairly high level of communicative competence in teaching grammar in order to carry out his role effectively. The students in English Education Study Program are prepared for it, Campbell (2001) has pointed out that a good presentation includes how to deliver, presentation material, mastery of the material, timing, audience mastery, visual tool, and audience feedback. Presentation skills are not only important in the world of education, but also have a very significant influence on the success of the professional business field.

In the English Education Study Program of Billfath Basic English Grammar is a compulsory subject taken in the first semester. Grammar in its level, although at the basic level is still considered a difficult subject. Therefore an appropriate method is needed to provide good understanding and mastery so that each student has a strong foundation to study English courses in the following semester. Liaw (2009) besides conventional learning, learning with group discussion methods is needed. Sundrarajun and Kiely (2010) stated that individual oral presentations are thought to increase understanding and mastery of basic english grammar. This study aims to analyze whether group discussions and presentations can improve the first semester Lamongan Billfath University students' understanding and mastery of Basic English Grammar courses.

\title{
METHODOLOGY
}

The study was conducted for one semester (14 meetings) with the subject of Basic English Grammar courses. The object of the study was 16 first semester Lamongan Billfath University students. Pretest is used to assess the initial abilities 
KARANGAN: Jurnal Kependidikan, Pembelajaran, dan Pengembangan, Vol 03, No 01, Bulan Februari, Tahun 2021, Hal 1-6

of each student. Students are divided into four groups based on the scor of the pretest. Students with above-average grades are appointed as group leaders. Lecture material is shared with students one week before the lecture day. The material includes all part of speech for basic English grammar; Nouns, Verb, Subject-Verb Agreement, Pronoun, Adjectives ad Adverbs, Conjunctions, and Prepositions. On the lecture day each group discussed the material presented by the lecturer. The final results of the study were assessed by the posttest.

After the posttest, each student chooses of the Basic English Course materials that have been thought to be presented. Chang (2011) proposes that by teaching grammar the teachers not only give the students the means to express themselves, but also fulfill their expectations of what learning foreign language involves. Assessment of presentation according to Selvi and Chandramohan (2016) includes delivery, material, time, audience interaction and use of visual tools.

The mean scores of pretest, posttest and presentation were analyzed by Mann-Whitney $\mathrm{t}$ test after normal data distribution was obtained but not homogeneous, using SPSS 25. The application of group discussions and presentations during the lecture process was analyzed descriptively.

\section{RESULT}

Descriptive statistical results in Table 1 show that the lowest and highest student pretest scores are 60 and 90, mean 70.94 and standard deviation 9.17. While the posttest score showed an average increase of 84.06 and a decrease in the standard deviation of The pretest, posttest and presentation variables were normally distributed as shown in Table 1 where each variable showed significance values of $0.182 ; 0.200 ; 0.158>0.05$.

The homogeneity test in Table 2 showed insignificant results $0.002<0.05$, meaning that the data was not homogeneous. Therefore, the non- parametric statistics of the Mann- Whitney t test are used to analyze the mean differences between all variables.

The Mann-Whitney $t$ test in Table 3 showed that the pretest score was significantly different from the posttest score and presentation score, which were 0.001 and $0.026<0.05$, respectively. While the posttest and presentation score did not show a significant difference, $0.276>0.05$.

Table 1. Descriptive Statistics of Pretest, Posttest and Presentation Scores; and Liliefors' Test of Normality

\begin{tabular}{lrrr}
\hline \multirow{2}{*}{ Values } & \multicolumn{3}{c}{ Variables } \\
\cline { 2 - 4 } & Pretest & Posttest & Presentation \\
\hline $\mathrm{N}$ & 16 & 16 & 16 \\
Minimum & 60 & 65 & 60 \\
Maximum & 90 & 95 & 95 \\
Mean & 70,94 & 84,06 & 79,69 \\
Std. Deviation & 9,17 & 8,8 & 11,18 \\
Liliefors' Test of & & & \\
Normality & 0,182 & 0,2 & 0,158 \\
\hline
\end{tabular}

Table 2. Levene's Test of Homogeneity

\begin{tabular}{lrrr}
\hline ANOVA & $\begin{array}{l}\text { Between } \\
\text { Groups }\end{array}$ & \multicolumn{1}{l}{$\begin{array}{l}\text { Within } \\
\text { Groups }\end{array}$} & \multicolumn{2}{c}{ Total } \\
\hline Sum of Squares & 1429,17 & 4295,31 & 5724,48 \\
Df & 2 & 45 & 47
\end{tabular}


KARANGAN: Jurnal Kependidikan, Pembelajaran, dan Pengembangan, Vol 03, No 01, Bulan Februari, Tahun 2021, Hal 1-6

\begin{tabular}{lrr} 
Mean Square & 714,58 & 95,45 \\
F & 7,486 & \\
Sig. & 0,002 & \\
\hline
\end{tabular}

Table 3. Mann-Whitney t Test

\begin{tabular}{ll}
\hline Mann-Whitney t Test & Asymp. Sig. (2-tailed) \\
\hline Pretest * Posttes & 0.001 \\
Pretest * Presentation & 0.026 \\
Posttest * Presentation & 0.276 \\
\hline
\end{tabular}

The ability to understand and master the Basic English Grammar course of students at the beginning of the lecture (pretest) is less evenly distributed and more below the average score of 70.94 which is 10 students (62.5\%). While 6 students $(37.5 \%)$ had a score above average. This is possible from the history of their English education in high school and also the interest of each student in learning English. Christison, Ann, Christian, Duffand Spada (2015) proposed that the interest and motivation of each student is visible from the beginning to the end of the lecture, where students with high interest and motivation have a better score because they are always interested in the material being studied.

Significant increase in understanding and mastery of Basic English Grammar course was seen at the end of the lecture, with an increase in the average posttest score of 84.06 and a decrease in standard deviation since the number of students who scored above the average posttest rose to $62.5 \%$ (10 students). When compared with the average pretest there was a score increase of $87.5 \%$ (14 students).

The group discussion method is used to increase the interest and motivation and activeness of students in learning basic English grammar courses. During the lecture students are directed to discuss the material that the lecturers have delivered with their respective groups. Direct observation during lectures indicates that group discussions provide flexibility and comfort for students who are shy/introverted by discussing or asking questions about the material to other students in the group. This provides a comfortable and conducive learning environment for all students. Tanaka (2017) conducive and highly motivated learning groups have a positive effect on the success of the learning process, and vice versa. The group discussion has a significant effect in increasing the final score of students both those who have low and high learning motivation. Furthermore Menggo, Sebastian, Seken, and Ratminingsih (2013) say that conventional teaching methods do not have a significant effect on students, it is possible because the method is less interactive so students are less motivated in learning.

For most students presentation is a scary thing, stressful and needs to be avoided. This is due to a lack of confidence to speak in front of many people. This can be seen from several individual student presentation performances which are not maximal in terms of delivery, material, audience mastery and use of visual tools. However, these results are efforts that need to be appreciated, because most students made their presentations for the first time. During the lecture there were 3 students who did not take the presentation test, allegedly lacked confidence and were not ready to conduct presentation tests, so they were not included in the data analysis. 
KARANGAN: Jurnal Kependidikan, Pembelajaran, dan Pengembangan, Vol 03, No 01, Bulan Februari, Tahun 2021, Hal 1-6

Student presentation skills are not evenly distributed, as seen from the standard deviation of the presentation test score of 11.18. The percentage score below and above the average presentation test score is 50\%. Ozdemir and Tekin (2016) demonstrates presentation skills must be mastered by every student, especially for students majoring in education who will become teachers' Therefore training and habitual presentation are needed so that students' self-confidence and presentation skills increase. Turner, Karen, Roberts, Caroline, and Liz (2013) stated that In the student's point of view, the Presentation test makes and forces them to better understand Basic English Grammar material, even though discomfort and anxiety occur during their presentation.

\section{CONCLUSION AND SUGGESTION}

The group discussion method was significantly able to improve students' understanding and mastery of basic English grammar courses and to help mastering presentation material. The results of the Mann-Whitney t test between pretest and posttest scores and between pretest and presentation scores were 0.001 and $0.026<$ 0.05 . The posttest score and presentation did not differ significantly, $0.276>$ 0.05 . The students' main problem in the presentation test was the lack of selfconfidence and not being used to speaking in front of the class, therefore further studies are needed to overcome the problem.

\section{REFERENCES}

Campbell, Kim Sydow, David L. Mothersbaugh, Charlotte Brammer and Timothy Taylor. 2001. "Peer versus Self-Assessment of Oral Business." Business Communication Quarterly Volume 64 No. 3 (September, 2001): 23-42. https://doi.org/10.1177/108056990106400303

Canale, M., Swain, M. 1980. "Theoretical Bases of Communicative Approaches to Second Language Teaching and Testing”. Applied Linguistics Volume 1, No.1: 1-47. https://doi.org/10.1093/applin.I.1.1

Chang, Shih-Chuan. 2011. "A Contrastive Study Grammar Translation Method and Communicative Approach in Teaching English Grammar". Journal of ELT Volume 4 No.2 (January, 11): 13-14. https://doi.org/10.5539/elt.v4n2p13

Christison, MaryAnn, Donna Christian, Patricia A. Duff, and Nina Spada. 2015. "Teaching and learning English grammar: research findings and future directions." New York: Routledge.

Farrell, Thomas S.C. 1999. "The Reflective Assignment: Unlocking Pre-Service English Teachers' Beliefs On Grammar Teaching." RELC Journal Volume 30 No. 2 (December, 1999): https://doi.org/10.1177/003368829903000201.

Ghofur, Abd. 2013. "Another Alternative in Teaching English: A Theoretical Perspective." Okara Vol. 7 No. 2 (November, 2013): 61-78. http://dx.doi.org/10.19105/ojbs.v7i2.447

Hwang, Wu-Yuin, Yung-Hui Li, and Rustam Shadiev. 2018. "Exploring effects of discussion on visual attention, learning performance, and perceptions of students learning with STR-support". Computers \& Education Volume 116 (January, 2018): 225-236. https://doi.org/10.1016/j.compedu.2017.09.015.

Kerby, Debra and Jeff Romine. 2009. "Develop Oral Presentation Skills Through Accounting Curriculum Design and Course-Embedded Assessment." Journal of Education for Business Volume 85, Issue 3 (July, 2009):172179. http://dx.doi.org/10.1080/08832320903252389. 
KARANGAN: Jurnal Kependidikan, Pembelajaran, dan Pengembangan, Vol 03, No 01, Bulan Februari, Tahun 2021, Hal 1-6

Liaw, En-Chong. "Teacher efficacy of pre-service teachers in Taiwan: The influence of classroom teaching and group discussions." Teaching and Teacher Education Volume 25, Issue 1 (January, 2009): 176-180. http://dx.doi.org/10.1016/j.tate.2008.08.005.

Liontas, John I., 2018. "Teaching Grammar: Form-Meaning Mapping” The TESOL Encyclopedia of English Language Teaching: 1-7. https://doi.org/10.1002/9781118784235.eelt0064

Menggo, Sebastian, Ketut Seken, and Made Ratminingsih. 2013. "The Effect of Discussion Technique and English Learning Motivation toward Students' Speaking Ability". Jurnal Pendidikan Bahasa Inggris Indonesia Undiksha Volume 1 (2013): 1-10

Ozdemir, Oguzhan and Ahmed Tekin. 2016. "Evaluation of the presentation skills of the pre-service teachers via fuzzy logic." Computers in Human Behavior Volume 61 (August 2016): http://dx.doi.org/10.1016/j.chb.2016.03.013.

Selvi, R.Tamil. and G. Chandramohan. "Peer Assessment of Oral Presentation: An Investigative Study of Using Clickers in First-Year Civil Engineering Institution." IEEE $8^{\text {th }}$ International Conference on Technology for Education (December 2016): 132-135. https://doi.org/10.1109/T4E.2016.034.

Sundrarajun, Chutamas and Richard Kiely. "The Oral Presentation as a context for learning and assessment." Innovation in Language Learning and Teaching Volume4, Issue 2 (July 2010): 101-117. http://dx.doi.org/10.1080/17501220903125021.

Tanaka, Mitsuko. "Examining EFL vocabulary learning motivation in a demotivating learning environment" System Volume 65 (April 2017):130138. https://doi.org/10.1016/j.system.2017.01.010

Turner, Karen, Lynn Roberts,Caroline Heal, and Liz Wright. "Oral presentation as a form of summative assessment in a master's level PGCE module: the student perspective." Assessment \& Evaluation in Higher Education Volume 38, Issue 6 (July 2013):662-673. http://dx.doi.org/10.1080/02602938.2012.680016 